\title{
Biological and Chemical Control of Sclerotinia sclerotiorum using Trichoderma spp. and Ulocladium atrum and Pathogenicity to Bean Plants
}

\author{
Girlene Soares de Figueirêdo ${ }^{1}$, Lívio Carvalho de Figueirêdo ${ }^{1}$, Francinete Carla Nunes \\ Cavalcanti $^{1}$, Angela Coimbra dos Santos ${ }^{1}$, Antonio Felix da Costa ${ }^{2}$ and Neiva Tinti de \\ Oliveira $^{1 *}$ \\ ${ }^{1}$ Departamento de Micologia; Universidade Federal de Pernambuco; Av. Moraes Rego, s/n; 50670-901; Recife - \\ PE - Brasil. ${ }^{2}$ Empresa Pernambucana de Pesquisa Agropecuária; Av. Gal. San Martin, 1371; 50761-000; Recife - \\ PE - Brasil
}

\begin{abstract}
Four isolates of Sclerotinia sclerotiorum were tested for pathogenicity in IPA-10 variety bean plants (Phaseolus vulgaris L.), and all were pathogenic. Biological control in vitro was evaluated using eight isolates of Trichoderma spp. and, one of Ulocladium atrum. Chemical control in vitro with fungicides Thiophanate methyl, Iprodione and Carbendazim was also tested. Except U. atrum, all Trichoderma isolates showed antagonistic potential against S. sclerotiorum, where isolate 3601 presented the best performance. Thiophanate methyl chemical control was the most efficient. This fungicide and isolate 3601were compared in vivo in greenhouse. There was statistical difference between the treatments, and the application of fungicide and antagonist before the pathogen was the most efficient approach, reducing the percentage of pathogenicity to $32.94 \%$ and $37.04 \%$, respectively.
\end{abstract}

Key words: S. sclerotiorum, Trichoderma, antagonist, bean plant.

\section{INTRODUCTION}

Several diseases affect the bean plants in Brazil, some causing great damages such as anthracnose, angular leaf spot, fusariosis and white mold caused by Sclerotinia sclerotiorum (Lib.) DeBary. The latter has a circle of hosts consisting of 408 species and 278 genera of plants approximately (Boland and Hall, 1994). Cother (2000) observed that the isolates of Australian specimens of $S$. sclerotiorum were pathogenic to 45 plant species comprised in 21 families of native plants from the east Australian cost. Lithourgidis et al (2003) also noticed non-specific host of isolates obtained from bean and cucumber in leguminous trees, both inducing the symptoms in host under test. This pathogen has been associated to significant loss of commercial yield of crops of beans irrigated at the central region of Brazil (Charchar et al., 1999). In Pernambuco state, the incidence of white mold at the Agreste Meridional region of the state has been observed in small commercial cultivars (Miranda et al., 2002).

This pathogen control through the conventional practice and chemical fungicide usage is the most common method. However, this technique is incredibly expensive and presents a very negative ecological impact due to toxic residues (Rocha and

\footnotetext{
*Author for correspondence: nto@ufpe.br
} 
Oliveira, 1998). Another prominent practice of management of plant diseases by fungi is the use of biocontrol. Several species of Trichoderma have been reported as potential biocontrol agents of phytopathogenic fungi on soil (Chet, 1987), including S. sclerotiorum (Trutmann and Keane, 1990; Pereira et al., 1996; Gracia-Garza et al., 1997; Illipronti Júnior and Machado, 1998; Lobo Júnior and Abreu, 2000). Earlier studies have shown U. atrum as a hopeful biocontrol agent of some phytopathogenic fungi, such as species of Botrytis, mainly B. cinerea (Kohl et al., 2000; Boff et al., 2001). However, studies about the efficiency of $U$. atrum as potential biocontrol agent of $S$. sclerotiorum are very scarce, and only the works by Li et al. (2003) are available about this topic.
Considering the difficulties of controlling $S$. sclerotiorum, the present work aimed to study the possibility of biological control of S. sclerotiorum in bean plants by species of Trichoderma and Ulocladium atrum, providing resources for further studies on biocontrol in field conditions.

\section{MATERIALS AND METHODS}

Isolates of $S$. sclerotiorum, Trichoderma spp. and $U$. atrum used in the study

Four isolates of S. sclerotiorum and nine isolates of antagonists from different localities, hosts and substrates were used in this study as shown in Table 1.

Table 1 - Isolates of Sclerotinia sclerotiorum and antagonists Trichoderma spp.and Ulocladium atrum

\begin{tabular}{|c|c|c|c|}
\hline Species & Isolate & Origin & Substrate \\
\hline S. sclerotiorum & 806 (micoteca - URM) & USA & soil \\
\hline S. sclerotiorum & Ss5 (EMBRAPA- rice and beans) & Rio Grande do Sul- Brazil & soy \\
\hline S. sclerotiorum & Ss17 (EMBRAPA- rice and beans) & Distrito Federal- Brazil & lettuce \\
\hline S. sclerotiorum & Ss 11 (micoteca - URM) & Pernambuco- Brazil & beans \\
\hline T. viride & 2745 (micoteca - URM) & Pernambuco- Brazil & sugarcane \\
\hline T. viride & 2820 (micoteca - URM) & Alagoas- Brazil & sugarcane \\
\hline T. harzianum & 3601 (micoteca - URM) & Paraná- Brazil & Soil \\
\hline U. atrum & 3180 (micoteca - URM) & Pernambuco- Brazil & barley \\
\hline T. aureoviride & 4912 (micoteca - URM) & Pernambuco- Brazil & bean rhizosphere \\
\hline T. aureoviride & 4913 (micoteca - URM) & Pernambuco- Brazil & bean rhizosphere \\
\hline T. aureoviride & 4924 (micoteca - URM) & Pernambuco- Brazil & bean rhizosphere \\
\hline T. aureoviride & 4915 (micoteca - URM) & Pernambuco- Brazil & bean rhizosphere \\
\hline T. aureoviride & 4916 (micoteca - URM) & Pernambuco- Brazil & bean rhizosphere \\
\hline
\end{tabular}

Pathogenicity Test of isolates of $S$. sclerotiorum on bean plants

Two types of pathogen inoculum were prepared using cultures of $S$. sclerotiorum grown for 10 days on PDA (Potato Dextrose Agar) medium at $28^{\circ} \mathrm{C}$. The first type of inoculum consisted of sclerotia and the second one was a suspension of mycelium-agar triturated with sterilized distilled water.

$P$. vulgaris plants of variety IPA-10 were cultivated in plastic pots containing $3 \mathrm{~kg}$ of soil (sandy claim loam soil) sterilized with methyl bromide. The inoculation was carried out after 15 days of planting. The sclerotia were set at a depth of $3 \mathrm{~cm}$ in the soil and $2 \mathrm{~cm}$ far from the stalk, each plant receiving three sclerotia. The inoculum suspension was also applied to the soil next to the roots at a depth of $5 \mathrm{~cm}$, and each plant received $20 \mathrm{~mL}$ of inoculum. The controls received $20 \mathrm{~mL}$ of sterilized distilled water without inoculum of $S$. sclerotiorum. All plants were kept in greenhouse conditions and the experimental design was completely randomized with ten repetitions for each treatment.

The plant symptoms of disease isolates of pathogen were evaluated at 10, 15, 20 and 25 days after inoculation and consisted of observing typical symptoms according to Hall and Phillips (1996). The data were submitted to statistical tests to compare isolates. A model of binomial multivariate analyses was applied according to GEE methodology (Prentice and Zhao, 1991) with structure of permutable correlation to better explain the percentage of leaves, petioles and stalks infected.

\section{S. sclerotiorum Biological Control in vitro with isolates of Trichoderma spp and $U$. atrum.}

The rate of mycelium growth of fungal isolates was calculated by daily measurements of the 
diameter of the colonies in two opposite directions using a millimeter ruler for six days.

The matching method between the antagonist and phytopathogen described by Dennis and Webster (1971) was used to determine the antagonistic potential of isolates of Trichoderma and U. atrum against the isolates of $S$. sclerotiorum. The method consisted of inoculating the Petri dishes containing PDA, with disks of mycelium-agar from the phytopathogen and antagonists on halfway points, $7 \mathrm{~cm}$ apart from each other, and $1 \mathrm{~cm}$ away from the edge of the plate. Then was considered the rate of mycelium growth of each isolate in such a way that the colonies could reach simultaneously the center of the plate. Daily measures were carried out in opposite directions until the meeting of the two mycelia and/or until one of the two fungi were overlaid by the other.

Ranking based on Bel et al. (1982) scale was used in order to evaluate the antagonistic potential of isolates of Trichoderma and $U$. atrum and interactions between the isolates were observed under optical microscopy (Table 2).

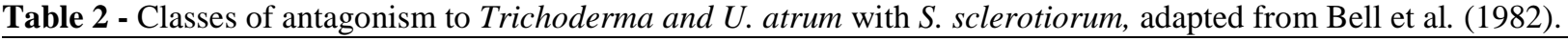

\begin{tabular}{cl} 
Class & \multicolumn{1}{c}{ Characteristic } \\
\hline 1 & $\begin{array}{l}\text { Trichoderma or Ulocladium grows and covers completely all colonies of S. sclerotiorum and } \\
\text { medium surface. }\end{array}$ \\
3 & $\begin{array}{l}\text { Trichoderma or Ulocladium grows and covers } 2 / 3 \text { of medium surface. } \\
\text { Antagonists and phytopathogen colonize each one, half of the medium surface and no one seems to } \\
\text { dominate the other. }\end{array}$ \\
4 & $\begin{array}{l}\text { S. sclerotiorum colonizes } 2 / 3 \text { of medium surface. } \\
\text { S. sclerotiorum grows and covers completely all colonies of Trichoderma or Ulocladium atrum and } \\
\text { the medium surface. }\end{array}$ \\
\end{tabular}

\section{Chemical Control of $S$. sclerotiorum in vitro}

Three fungicides were selected for the present study: Thiophanate methyl, Carbendazim, and Iprodione. These were incorporated into PDA medium, following Caldari Junior (1998) in four different concentrations of the active ingredient (1, 10,50 and 100ppm). Afterwards, discs of mycelium-agar with isolates of the phytopathogen were inoculated in medium containing fungicides, with four repetitions for each treatment; including control inoculated in fungicide-free medium and maintained at $28^{\circ} \mathrm{C}$.

Mycelial growth was measured at regular intervals (24 h) to evaluate the chemical control and alterations in macroscopic aspects of colonies. The data were submitted to statistical analysis in order to compare the efficiency of fungicides.

The experiment was arranged in a complete randomized $4 \times 3 \times 4$ factorial scheme represented by four isolates of pathogen; three fungicides; four concentrations of active ingredient with four repetitions for each treatment, and control. Variance analysis and means were compared using Tukey test at $5 \%$ of probability.

\section{Comparison between biological and chemical control in bean plants in vivo.}

The best performance in vitro of Trichoderma isolate for biocontrol and the most efficient fungicide in chemical control of $S$. sclerotiorum were both selected and tested in vivo in greenhouse. Bean seeds were seeded in pots containing sterilized soil with methyl bromide. After 15 days of plant growth, phytopathogen and then antagonist and fungicide were employed in different treatments, except in one, where the antagonist was inoculated before the pathogen. The different treatments are shown in Table 3. The antagonist was added to the soil of the pots with bean plants, being introduced in autoclaved rice as described by Noronha et al. (1996), in a concentration of $2 \mathrm{~g}$ of inoculum $/ \mathrm{kg}$. The fungicide used in this phase of the study was applied as recommended by manufacturer (powder diluted in water sprinkled on the plants). The evaluation of the results was carried out as described above when testing the pathogenicity. 
Table 3 - Treatment scheme and application time of antagonist and fungicide selected to compare chemical and biological control of Sclerotinia sclerotiorum.

\begin{tabular}{ll}
\hline Treatment & Inoculation time/ antagonist or fungicide application \\
\hline $3601 \times$ Ss 11 & antagonist employed 8 days before the pathogen. \\
$\mathrm{Ss} 11=3601$ & antagonist employed at the same time as the pathogen \\
$\mathrm{Ss} 11 \times 3601$ & antagonist employed 8 days after the pathogen. \\
$\mathrm{S} 11 \mathrm{x}$ thiophanate methyl & fungicide employed as recommended by manufacturer \\
\hline
\end{tabular}

\section{RESULTS AND DISCUSSION}

\section{Pathogenicity of $S$. sclerotiorum to bean plants}

The first symptoms of white mold were observed on the first evaluation, on tenth day after inoculations took place. The leaves turned yellow, wilted and presented humid lesions on petioles, branches and stalks in advanced stage culminating in plant death, with the presence of white mycelium and esclerotia in stalks, branches and immature beans. Symptoms were considered as being severe for four tested isolates, 25 days after inoculation, contrasting with the plants used as control, which showed no symptoms. The four isolates tested for pathogenicity were isolated again using plants with symptoms and were identical to those seen in macroscopic and microscopic observation.

All the tested isolates were pathogenic to bean plants. Isolates Ss11, Ss17 and 806 induced the most severe disease symptoms, with 89.4, 87.2 and $89.8 \%$ of symptoms, respectively, whereas isolate Ss5 showed the lowest percentage of symptoms with $76.5 \%$ (Table 4). Statistical analyses of the data showed differences between the isolates, and only isolate Ss5 was significantly less pathogenic than the other ones (Table 5). The isolates caused pathogenicity, which was possible due to the suitable climate conditions during the experiment, where the average maximum and minimum temperatures were 33.2 and $22^{\circ} \mathrm{C}$ respectively, and the maximum and minimum relative humidity values 90.8 and $47.7 \%$ respectively. Bianchini et al. (1997) stated that mild temperatures associated whith high humidity were essential factors to the development of plant damages caused by $S$. sclerotiorum.

Table 4 - Percentage of pathogenicity presented by isolates of Sclerotinia sclerotiorum in Phaseolus vulgaris plants.

\begin{tabular}{cc}
\hline Isolate & Pathogenicity to Phaseolus vulgaris (\%) \\
\hline Ss11 & 89.4 \\
806 & 89.8 \\
Ss17 & 87.2 \\
Ss5 & 76.5 \\
\hline
\end{tabular}

Table 5 - Comparison between treatments and their respective statistics for percentages of pathogenicity of Sclerotinia sclerotiorum in Phaseolus vulgaris plants.

\begin{tabular}{cc}
\hline Treatments & Statistical Correspondents \\
\hline Control x Ss11 & $2.885827 \times 0.00000000^{*}$ \\
Control x Ss17 & $2.885828 \times 0.00000000^{*}$ \\
Control x Ss5 & $2.885827 \times 0.00000000^{*}$ \\
Control x 806 & $2.885829 \times 0.00000000^{*}$ \\
Ss11 x Ss17 & $2.725556 \times 0.60162255$ \\
Ss11 x Ss5 & $3.095548 \times 0.07850673^{*}$ \\
Ss11 x 806 & $1.024242 \times 0.91938787$ \\
Ss17 x Ss5 & $3.605397 \times 0.05759230^{*}$ \\
Ss17 x SsM & $4.622716 \times 0.49656424$ \\
Ss5 x 806 & $4.992292 \times 0.02546046^{*}$ \\
\hline
\end{tabular}

*Significant at 0.10 level of probability. Statistical correspondents of Waldo f matrix of covariance were calculated to determine statistical differences between treatments. 
Bolland (1997) reported the existence of a large range of hosts to $S$. sclerotiorum. Charchar et al (1999) tested isolates obtained from cotton in different species of hosts such as: bean, okra and cotton plants and observed that all were infected by the phytopathogen. Cother (2000) observed that the isolates of native Australian fungi were pathogenic to 45 plant species in 21 families of native plants from the Australian east cost. Lithourgidis et al (2003) also noticed the host nonspecificity of isolates obtained from bean and cucumber in leguminous trees, both inducing symptoms in host under test.

This study also observed that the pathogen was not specific, therefore the isolates tested in beans from different origins of host presented very close percentages of pathogenicity, and isolate 806 showed the largest percentage of pathogenicity $(89.8 \%)$ and Ss5 the lowest one (76.5\%).

\section{Antagonistic potential of isolates of Trichoderma spp. and Ulocladium atrum against Sclerotinia sclerotiorum in vitro}

Of the nine antagonist isolates evaluated for potential biocontrol of $S$. sclerotiorum, only three showed satisfactory action (3601, 4915 and 4916), being from class 1 of antagonism, adapted from Bell et al.(1982). The other isolates of Trichoderma spp. presented mild antagonistic potential, pertaining to class 2 of antagonism. Isolate 3180 (U. atrum) didn't show antagonistic action to $S$. sclerotinia scerotiorum (Table 6). Li et al. (2003) reported the existence of antagonistic potential of $U$. atrum against $S$. sclerotiorum, although this antagonistic effect was not observed in this work. In the present study the only tested isolate of $U$. atrum didn't show antagonistic potential against the pathogen. This could be due to the preservation of the isolate, which was obtained from the Micoteca URM collections. According to Smith and Onions (1994) the preservation might microorganisms may alter or inactivate important physiological characteristics such as pathogenicity, sporulation or enzymes liberation and other compounds.

Table 6 - Classes of antagonism adapted from Bell et al. (1982) for isolates of Trichoderma spp and Ulocladium atrum against isolates of Sclerotinia sclerotiorum.

\begin{tabular}{cc}
\hline Class of antagonism & Isolate \\
\hline 1 & $3601,4915,4916$ \\
3 & $2820,2745,4912,4913,4914$ \\
\end{tabular}

Besides mycelium growth, the level of sporulation of antagonist isolate was also observed. The production of spores of isolates $3601,4914,4915$, 4916 and 3180 was not affected when in contact with pathogen, but isolates 4912 and 4913, presented a slight decrease in sporulation, while isolates 2745 and 2820 hardly produced spores. Batista (2002) reported that the process of sporulation would be possibly a favorable characteristic to antagonists, therefore, new inoculum was desirable in the presence of pathogen, inhibiting its actions, due to greater density of antagonist inoculum.

The inhibition of mycelium growth of $S$. sclerotiorum was more intense with isolates 2745 (T. viride), 2820 (T. viride), 4912 (T.aureoviride), 4913 (T.aureoviride) and 4914 (T. aureoviride) that colonized $2 / 3$ of the plate without growing over the pathogen. This inhibition was probably related to the capacity of production of antibiotic substances by these antagonists, which could affect the pathogen development (Chet and Baker, 1981; Blakeman and Fokkema, 1982; Papavizas, 1985). Campbell (1989) reported some effects caused by antibiotic substances liberated by antagonists such as reduction or paralysis of mycelium growth and sporulation, reduction in spore germination, besides distortions on hyphae and plasmolysis.

Microscopic observation of the interaction area between the colonies of antagonists and phytopathogen showed morphological alterations such as: parallel growth of antagonist and of pathogen, formation of hyphae rings, with rolling up of hyphae, hyphae fragmentation, mycelium without protoplasmatic content and the penetration of the hyphae from $S$. sclerotiorum by all Trichoderma isolates.

Elad (2000) related the consecutive stages involving mycoparasitism of pathogenic fungi by species of Trichoderma, such as: chemotrophic growth (where exudates of pathogen attract 
antagonist); recognition between the phytopathogen and antagonist; adhesion to the pathogen hyphae and finally, degradation, caused by the secretion of enzymes such as proteases and chitinases to degrade and penetrate in the pathogen cell wall. According to Brunner et al. (2003), the enzyme $73-\mathrm{KDA} \quad \mathrm{N}$-acetyl- $\beta$-D-glucosaminidase was related to genes involved in induction of chitinase, and this enzyme was the most relevant for biocontrol because was related with the degradation of fungi cell wall.

The antagonist isolates presented rings of hypha when matched with the pathogen. Elad et al. (1987), studying biological control of Rhizoctonia solani by Trichoderma spp., observed that these rings were frequent during matching and then related this structure to parasitism. However, Rocha and Oliveira (1998) observed that even lacking the mycelium from the host, in this case Colletotrichum gloeosporioides, there were rings of hyphae formed by Trichoderma, suggesting that these structures were not directly related to mycoparasitism.

\section{Chemical control in vitro of isolates de $S$. sclerotiorum.}

The three tested fungicides were able to reduce significantly the mycelium growth of four isolates of S. sclerotiorum. Thiophanate methyl showed the best results even at lower concentration of active ingredient (1ppm), affecting considerably the mycelium growth of pathogen and at other concentrations tested $(10,50$ and $100 \mathrm{ppm})$ no growth of pathogen was observed. For other fungicides the concentration of the active ingredient able to inhibit the pathogen growth varied, with $10 \mathrm{ppm}$ for Iprodione and $50 \mathrm{ppm}$ for Carbendazim (Table 7). All of the S. sclerotiorum isolates analyzed here were not able to grow at a concentration of $100 \mathrm{ppm}$ of all the tested fungicides.

Table 7 - Effect of fungicides in different concentrations of active ingredient on mycelium growth of Sclerotinia sclerotiorum, after 144 hours in BDA medium.

\begin{tabular}{cccc}
\hline Isolate & \multicolumn{3}{c}{ Fungicides } \\
\hline & Iprodione & Thiophanate methyl & Carbendazim \\
Ss5 & $33.6058 \mathrm{bB}^{1}$ & $18.3200 \mathrm{cC}$ & $44.7227 \mathrm{bA}$ \\
SsM & $34.6774 \mathrm{aB}$ & $22.5358 \mathrm{bC}$ & $46.6329 \mathrm{aA}$ \\
Ss11 & $33.4899 \mathrm{bB}$ & $18.4951 \mathrm{cC}$ & $45.3339 \mathrm{bA}$ \\
Ss17 & $33.3406 \mathrm{bB}$ & $25.0294 \mathrm{aC}$ & $45.1590 \mathrm{bA}$ \\
\hline
\end{tabular}

${ }^{1}$ Mean of four replications $(\mathrm{cm})$. Means transformed by $\mathrm{y}=\sqrt{\mathrm{x}+1}$, followed by the same letter did not differ at $5 \%$ of probability in column (capital letters) or in line (lower-case letters) by Tukey test

Mueller et al. (2002) studied the efficiency of Thiophanate methyl and other fungicides in chemical control of $S$. sclerotiorum and showed that this fungicide was efficient in chemical control of the pathogen at $7 \mu \mathrm{g} / \mathrm{mL}$. Kimura et al (2001) tested 19 fungicides including Iprodione and Thiophanate methyl against Botrytis cinerea and proved that iprodione and procimidone were the most efficient against this pathogen overcoming results obtained for Thiophanate methyl. Matheron and Matejka (1989) compared several fungicides including iprodione and stated that although its efficacy against $S$. sclerotiorum tends to a mild effect, becoming stable action at high concentrations. Studies of Brenneman et al (1987) and Poter and Philipps (1985) showed the resistance of $S$. minor to several fungicides of the group of dicarboxamidas, including iprodione and vinclozolina. Vital (1990) observed the growth of Sclerotium coffeicola in concentrations until 2000 ppm of iprodione, which would make this control method inappropriate.

\section{Comparison of chemical and biological control in vivo.}

All the treatments were statistically significant in relation to controls. The comparisons between statistical correspondents indicated that treatments 3601XSs11 and Ss11XThiophanate methyl were the most efficient in the chemical control of $S$. sclerotiorum, decreasing the symptoms induced by pathogen in more than $30 \%$ in relation to controls that presented high levels of incidence $(87.25 \%)$. The treatments Ss11=3601 and Ss11X3601 reduced the levels of incidence of white mold 16.21 and $7.05 \%$, respectively (Fig. 1). 


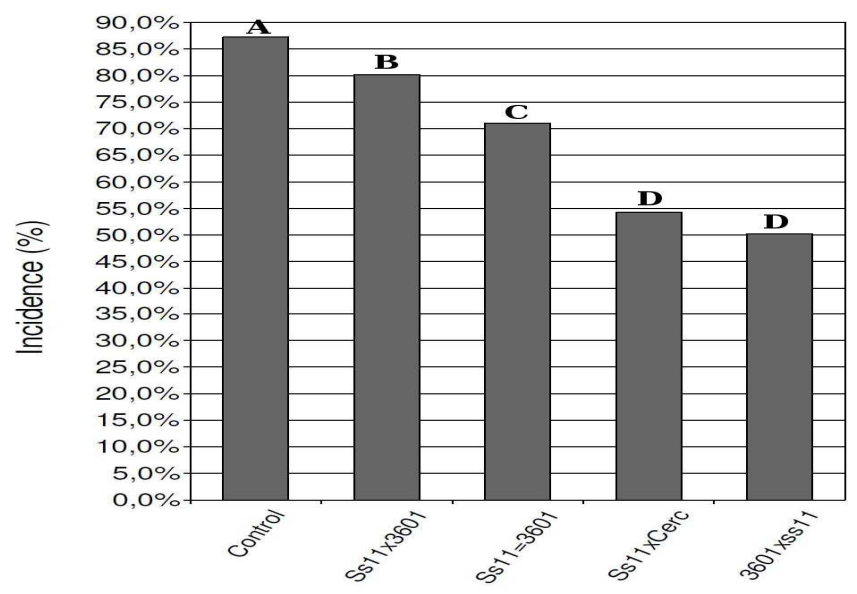

Figure 1 - Incidence levels of white mold caused by Sclerotinia sclerotiorum, in different treatments. Means followed by the same letters did not differ at the $10 \%$ level of the probability.

These results suggested a correlation between time of application of antagonist and the best control of pathogen. As soon as the antagonist is applied, the better is the performance against the pathogen. Jackish (1996) used similar methods and observed that no treatment had desirable action of Trichoderma spp., except when T. koningii was applied $24 \mathrm{~h}$ before the pathogen. Rocha and Oliveira (1998) found similar results studying the action of Trichoderma spp. against Colletotrichum gloeosporiodes in passion fruit tree. Bolland (1997) tested several agents of biocontrol, including $T$. viride and fungicide benomyl, for controlling white mold in bean plants and noticed no significant difference between these two forms of control. Both the treatments were efficient; however, such results were observed when environmental conditions were not favorable to the development of disease. Cardoso et al. (1997) observed in comparative studies between chemical and biological controls of root-rot of bean plants that Trichoderma sp. was not efficient when compared to some fungicides tested. Pereira et al. (1996) held forth integral control of $S$. sclerotiorum, showing solarization as one of the most efficient way of controlling this pathogen, followed by application of species of Trichoderma. However, chemical control with
Iprodione was inefficient, even in other associations with other forms of control.

The reduction in the incidence of diseases by using chemical control with Thiophanate methyl was considered low. Regarding the results obtained in vitro and greenhouse, this low reduction would be more consistent in field experiments, on natural soil, where other chemical, and mainly biological factors, could interfere in this kind of control (Kimati, 1995). The form of fungicide application (conventional application) coud be another factor to be considered when analyzing this low level of pathogen control. Oliveira et al. (1995) and Vieira et al. (2003) stated the importance of application know-how in relation to fungicides used to control the white mold, reinforcing the evident efficiency of fumigation and chemigation in detriment of compared to conventional application methods.

\section{ACKNOWLEDGEMENTS}

The authors express deep gratitude to CNPq/RENEBRA and IPA (Enterprising of Agriculture Research in the State of Pernambuco) for the support during the completion of the present research. 


\section{RESUMO}

Quatro isolados de Sclerotinia sclerotiorum, foram testados quanto à patogenicidade em plantas de feijão, variedade IPA-10 sendo que todos se mostraram patogênicos. Foram avaliados o controle biológico e químico in vitro, utilizando-se oito isolados de Trichoderma e um de Ulocladium atrum, e o controle químico in vitro, com os fungicidas Tiofanato metílico, Iprodione e Carbendazim. Com exceção de $U$. atrum todos os isolados dos antagonistas mostraram potencial antagônico contra S. sclerotiorum, destacando-se o isolado 3601 como o de melhor desempenho. No controle químico, Tiofanato metílico foi o mais eficiente, sendo este fungicida e o isolado 3601 comparados in vivo em casa-de-vegetação. Foram observadas diferenças estatísticas entre os tratamentos, sendo que a aplicação do fungicida e do antagonista antes da introdução do patógeno foi mais eficiente, com redução do percentual de incidência em $32,94 \%$ e $37,04 \%$, respectivamente.

\section{REFERENCES}

Batista D. C. (2002), Manejo integrado da murcha de Fusário do maracujazeiro. 89pp. Ms Sc. Thesis, Universidade Federal Rural de Pernambuco, Recife, PE.

Bell, D. K.; Wells, H. D.; Markham, C. R. (1982) ,In vitro antagonism of Trichoderma species against six fungal plants pathogens. Phytopathology, 72, 379382.

Bianchini, A.; Maringoni, A. C.; Carneiro, S. M. T. G. (1997), Doenças do feijoeiro. In Manual de Fitopatologia: Doenças das Plantas Cultivadas,. Kimati, T. H.; Bergamin Filho, A.; Amorim, L. eds 3th. São Paulo, Agronômica Ceres. pp. 391-392.

Blakeman, J. P.; Fokkema, (1982) N. J. Potential for biological control of plant diseases on the phyloplane. Annual Review Phytopathology, 20, 167-192.

Bolland, G.; Hall, R. (1994), Index of plant hosts to Sclerotinia sclerotiorum. Canadian Journal of Plant Pathology, 16, 93-108.

Bolland, G. J. (1997), Stability analysis for evaluating the influence of environment on chemical and biological control of white mold Sclerotinia sclerotiorum of bean. Biological Control, 9, 7-14.

Boff, P.; de Kraker, Jr.; van Bruggen, A. H. C.; Gerlagh, M.; Köll, J. (2001), Conidial persistence and competitive ability of the antagonist Ulocladium atrum on strawberry leaves. Biocontrol Science Technology, 11, 623-636.
Brenneman, T. B.; Phipps, P. M.; Stipes, R. J. (1987), Control of Sclerotinia blight of peanut sensitivity and resistance of Sclerotinia minor to vinclozolin, iprodione, dicloran and PCNB. Plant Disease, St Paul 71, 87-90.

Brunner, K.; Peterbauer, C. K.; Mach, R. L. (2003), The nag1-N-acetylglucosaminidase of Trichoderma atroviride is essencial for chitinase induction by chitin and of major relevance to biocontrol. Current Genetic, 43, 289-295.

Caldari Júnior, P. (1998), Caracterização morfológica, esporulação e sensibilidade a fungicidas de isolados de Botrytis cinerea de flores e plantas ornamentais. 51 pp. Ms Sc Thesis, Escola Superior de Agricultura Luiz de Queiroz, Universidade de São Paulo, Piracicaba, SP, Brazil.

Campbell, R. (1989), Biological Control of Microbial Plant Pathologens. Sidney: C.U.P., 218 p.

Cardoso, J. E.; Silva, S. A. G.; Marques, E. E. (1997), Controle químico e biológico das podridões radiculares do feijoeiro comum. Fitopatologia Brasileira, 22, 39-44.

Charchar, M. J. D.; Anjos, J. R. N.; Ossipi, O.(1999), Ocorrência de nova doença do algodoeiro irrigado, no Brasil, causada por Sclerotinia sclerotiorum. Pesquisa Agropecuária Brasileira, 34, 1101-1106.

Chet, I.; Baker, R. (1987), Isolation and biocontrol potential of Trichoderma harzianum from soil naturally supressive to Rhizoctonia solani. Phytopathology, 71, 286-290.

Cother, E. J. (2000), Pathogenicity of Sclerotinia sclerotiorum to Chrysanthemoides monilifera ssp. rotundata (Bitoubush) and selected species of the coastal flora in eastern Australia. Biological Control, 18, 10-17.

Dennis, C. J.; Webster, J. (1971), Antagonism properties of species-groups of Trichoderma,III. hyphal interaction. Transactions of British Mycological Society, 57, 363-369.

Elad, Y. (2000), Biological control of foliar pathogens by means of Trichoderma harzianum and potential modes of action. Crop Protection, 19, 709-714.

Elad, Y.; Sadowski, Z.; Chet, I. (1987), Scanning electromicroscopical observations of early stages of interaction of Trichoderma harzianum and Rhizoctonia solani. Transactions British Mycological Society, 88, 259-263.

Gracia-Garza, J. A.; Reeleder, R. D.; Paulitz, T. C. (1997), Degradation of sclerotia Sclerotinia sclerotiorum by fungus gnats (Bradysia coprophila) and the biocontrol fungi Trichoderma spp. Soil Biological Biochemistry, 29, 123-129.

Hall, R.; Phillips, L. G. (1996), Evaluation of parameters to assess of white bean to white mold. Annual Report of The Bean Improvement Cooperative, 39, 306-307. 
Illipronti Júnior, M. A.; Machado, J. C. (1998), Comportamento antagônico a Sclerotinia sclerotiorum (Lib.) de Bary de fungos procedentes da região do Alto Paranaíba. Ciência e Agrotecnologia, 21, 232-236.

Jackisch, A. B. (1996), Estudo de Pythium em Nicotiana tabacum: patogenicidade, caracterização morfológica e esterásica, reação de cultivares de fumo ao patógeno e biocontrole através de espécies de Trichoderma. 75 pp. Ms Sc. Thesis, Universidade Federal de Pernambuco, Recife, PE.

Kimati, T. H. (1995) Controle químico. In Manual de Fitopatologia: princípios e conceitos. eds. T. H. Kimati, T. H.; A Bergamin Filho; L. Amorim. São Paulo: Agronômica Ceres. pp. 717-727.

Kimura, M. K.; Souza, P. E.; Castro, H. A.(2001), Sensibilidade in vitro de Botrytis cinerea a fungicidas. Ciência Agrotécnica, 25, 1150-1160.

Köhl, J; Gerlagh, M; Grit, G. (2000),. Biocontrol of Botrytis cinerea by Ulocladium atrum in different production systems of cyclamen. Plant Dis. 84, 569573.

Li, G. Q.; Huang, H. C.; Acharya, S. N. (2003), Antagonism and biocontrol potential of Ulocladium atrum on Sclerotinia sclerotiorum. Biological Control, 28, 11-18.

Lithourgidis, A. S.; Tzavella-Klonari, K.; Roupakias, D. G. (2003), The causal fungus of stem rot disease of faba beans in Greece. Journal of Phytopathology, 151, 631-635.

Lobo Júnior, M.; Abreu, M. S. (2000) Inibição do crescimento micelial de Sclerotinia sclerotiorum por metabólitos voláteis produzidos por alguns antagonistas em diferentes temperaturas e pH's. Ciência Agrotécnica, 24, 521-526.

Matheron, M. E.; Matejka, J. C. (1989), In vitro and field comparison of six new fungicides with iprodione and vinclozolin for control of leaf drop of lettuce caused by Sclerotinia sclerotiorum. Plant Disease, 73, 727-730.

Miranda, P.; Costa A.F., Coelho Netto, R. A. Pimentel M. de L., Tavares Filho, J. J. ,Oliveira L.R. (2002) Memórias da participação brasileira no "I Taller Internacional sobre la mancha angular del fríjol": Ocorrência da Mancha Angular em Pernambuco. Série Documentos , 132, EMBRAPA.

Mueller, D. S.; Derksen, R. C.; Ozkan, E. (2002), Efficacy of fungicides on Sclerotinia sclerotiorum and their potential for control of Sclerotinia stem rot on soybean. Plant Disease, 86, 26-31.

Noronha, M. A. et al. (1996), Seleção de isolados de Trichoderma spp. para o controle de Rhizoctonia solonia em feijoeiro. Summa Phytopathologica, 22, 156-162.

Oliveira, S. H. F. et al. (1995), Avaliação comparativa da fungigação e aplicação convencional de fungicidas para controle de Sclerotinia sclerotiorum em feijoeiro. Summa Phytopathologica, 21, 249-252.

Papavizas, G. C. (1985), Trichoderma e Gliocladium: biology, ecology and potencial for biocontrol. Annual Reviews of Phytopathology, 23, 23-54.

Pereira, J. C. R. et al. (1996), Controle integrado de Sclerotinia sclerotiorum. Fitopatologia Brasileira, 21 254-260.

Porter, D. M.; Philipps, P. M. (1985), Effects of three fungicides on mycelial growth, sclerotium production, and development of fungicide-tolerant isolades of Sclerotinia minor. Plant Disease, 69, 143146.

Prentice, R. L.; Zhao, L. P. (1991), Estimating equations for parameters in means and covariances of multivariate discrete and continuous responses. Biometrics, 47 825-839.

Rocha, J. R. S.; Oliveira, N. T. (1998), Controle biológico de Colletotrichum gloeosporioides, agente da antracnose do maracujazeiro (Passiflora edulis), com Trichoderma koningii. Summa Phytopathologica, 24, 180-183.

Smith, D.; Onions, A. H. S. (1994), The preservation and maintenance of livinf fungi. London: International Mycological Institute.122pp

Trutmann, P.; Keane, P. J.(1990), Trichoderma koningii as a biological control agent for Sclerotinia sclerotiorum in southern Australia. Soil Biological Biochemistry, 22, 43-50.

Vieira, R. F.; Pinto, C. M. F.; Paula Júnior, T. J.(2003) Chemigation with benomyl and fluazinam and their fungicidal effects in soil for white mold control on dry beans.Fitopatologia Brasileira, 28, 245-250.

Vital, M. J. S. (1990), Sclerotium coffeicola Bull: crescimento, controle biológico, químico e alguns hospedeiros. $104 \mathrm{f}$. Msc Thesis, Universidade Federal de Pernambuco, Recife, PE. 